\title{
Detection of Mycobacterium Tuberculosis among Infertile Patients Suspected with Female Genital Tuberculosis
}

\author{
Venkanna Bhanothu, ${ }^{1, *}$, Jane Theophilus ${ }^{1}$, Roya Rozati ${ }^{2}$ \\ ${ }^{1}$ Department of Zoology, UCS, Osmania University, Hyderabad, AP, India \\ ${ }^{2}$ MHRT Hospital \& Research Centre, Hyderabad, AP, India \\ *Corresponding author: venkanna_82@yahoo.co.uk, banothu.venkanna@gmail.com
}

Received October 29, 2013; Revised March 17, 2014; Accepted April 07, 2014

\begin{abstract}
Female genital tuberculosis (FGTB) is a symptomless disease that evidences itself only when it is investigated for infertility. Demonstration of the etiologic agent by $\mathrm{H} \& \mathrm{E}$ staining or Z-N staining for acid fast bacilli, smear microscopy, culture of menstrual blood, urine and sputum were often unsuccessful. We therefore, proposed to use the endo-ovarian tissue biopsies and pelvic aspirated fluids for the detection of FGTB among infertile women by conventional versus genotypic methods. A prospective case-control study was undertaken. A total of 302 specimens were collected from 202 infertile women highly suspected of having FGTB on laparoscopic examination and from 100 control women of reproductive age. Out of these 302 specimens, 150 (49.67\%) were premenstrual endometrial tissue biopsies (ETBs), 95 (31.46\%) were ovarian tissue biopsies (OTBs) and 57 (18.87\%) were pelvic aspirated fluids (PAFs). All specimens tested by conventional/ phenotypic methods were later compared with multi-gene/ multi-primer PCR (multi-gene PCR) method using four sets of primers for the detection of Mycobacterium tuberculosis (MTB) DNA in a single tube-single step reaction and correlated with laparoscopic findings. The presence of MTB DNA was observed in $49.5 \%$ of ETBs, $33.17 \%$ of OTBs and $5.44 \%$ of PAF specimens collected from highly suspected FGTB patients. All control women were confirmed as negative for tuberculosis. The conventional methods showed $99 \%$ to $100 \%$ specificity with a low sensitivity, ranging from $21.78 \%$ to $42.08 \%$ while H \& E staining showed a sensitivity of 51.48\%. Multi-gene PCR method was found to have a much higher sensitivity of $70.29 \%$ with MTB64 gene, $86.63 \%$ with $19 \mathrm{kDa}$ antigen gene at species and TRC4 element at regional MTB complex level and $88.12 \%$ with $32 \mathrm{kDa}$ protein gene at genus level (Pearson $\chi 2=214.612$, $1 \mathrm{df}$, McNemar's test value $<0.0001)$. The specificity of multi-gene PCR was $100 \%$. We suggest site specific sampling, irrespective of sample type and amplification of the $19 \mathrm{kDa}$ antigen gene in combination with TRC4 element as a successful multi-gene PCR method for the diagnosis of FGTB and differentiation of mycobacterial infection among endo-ovarian tissue biopsies and PAFs taken from infertile women.
\end{abstract}

Keywords: endo-ovarian tissue biopsy processing, conventional/ phenotypic methods, multi-gene/ multi-primer polymerase chain reaction, female genital tuberculosis (FGTB), Mycobacterium tuberculosis (M. tuberculosis)

Cite This Article: Venkanna Bhanothu, Jane Theophilus, and Roya Rozati, "Detection of Mycobacterium Tuberculosis among Infertile Patients Suspected with Female Genital Tuberculosis." American Journal of Infectious Diseases and Microbiology, vol. 2, no. 2 (2014): 22-33. doi: 10.12691/ajidm-2-2-1.

\section{Introduction}

Female Genital Tuberculosis (FGTB) which is commonly implicated as a cause of infertility [1,2,3,4,5], is a symptom-less, rare disease with non-specific, mild clinical pictures and low index of clinical suspicion. There are no reliable confirmatory investigative procedures to ascertain the cause of infertility $[4,5]$. This is the most common form of extrapulmonary tuberculosis (TB), accounting for about $27 \%$ (range, 14 to $41 \%$ ) worldwide [6]. The incidence of infertility in genital TB worldwide varies from $10-85 \%$ [5,6,7,8]; it is endemic in India, with an incidence of $58 \%$ [9] and majority are in the reproductive age group (15-45 years) [10]. In $80-90 \%$ cases, it affects women with menstrual irregularities accounting for about $27 \%$ of manifestations of FGTB [11], even this rate can be higher among patients with tubal factor infertility (39-41\%) [12].

Diagnosis and limitations: $M$. tuberculosis (MTB) is a facultative intracellular acid-fast gram-positive pathogenic bacterium capable of producing both a progressive disease and an asymptomatic latent infection [13,14]. It generates worrying effects by causing irreversible damage to the fallopian tube consequential in infertility which is hard to treat both by medical and surgical methods $[15,16]$. It is estimated that at least $11 \%$ of the patients lack symptoms and FGTB is often detected in diagnostic workup of women attending infertility clinics [17]. Thangappah et al, 
revealed that $57 \%$ of infertile women in whom the presence of TB was suspected on clinical grounds had a positive endo-TB-PCR test, whereas only $9.5 \%$ had a positive test with no clinical ground for suspicion [18]. Therefore, a high degree of suspicion assisted by intensive investigation is significant in the diagnosis of the disease. Though, the actual incidence may be under-reported due to asymptomatic, varied clinical presentations, diverse imaging, transforming laparoscopic results and a mixed bag of bacteriological and serological tests [4,5]. A positive chest X-ray for healed or active pulmonary tuberculosis, contact history, elevated erythrocyte sedimentation rate (ESR), positive tuberculin test and sampling by laparoscopy may specify the need for further investigations $[19,20,21]$. Studies such as serial sections of tissues need to be studied, because the lesions are frequently erratic and that a positive endometrial culture for TB, is found only in about $25 \%$ of cases of tuberculous endometritis as the endometrium is often focal and the functionalis layer is shed every four weeks (granulomas take two weeks to develop) [22,23]. Moreover, due to the cyclical shedding of the endometrium, granulomas do not have enough time to form, so the granulomatous endometrium may not show evidence of tuberculosis in all the cycles. Oophoritis is an inflammation of the ovaries, often seen in combination with salpingitis (inflammation of the fallopian tubes). It is a relatively rare condition, usually follows haematogenous spread and causes infertility. Since, there is no way to take the fallopian tubes out, sampling from the ovaries and endometrium was suggested for the detection of FGTB [24]. Use of menstrual blood for bacteriologic or molecular diagnosis has been recommended [25] but was reported to show low sensitivity [26]. Conventional/ phenotypic methods have slow and low detection rates and limited due to secondary nature of genital tuberculosis. Sampled sites may not represent the infected area and the infected site can be simply missed due to sparse number of paucibacillary nature of mycobacteria [18]. In addition, tissue reaction in those having tuberculosis may at times be atypical and bacteriologically mute [17]. These methods have poor sensitivity and specificity for the diagnosis of FGTB throughout the sub-clinical stages. On the other side, a range of PCR techniques have been mechanized for the detection of specific nucleic acid sequences of MTB and other mycobacteria [27]. Identification of genes encoding the virulence determinants, available targets in genome and highly expressing factors are current important markers in the detection of FGTB. Biological, molecular and immunological studies have resulted in identification of more than 33 different useful proteins, some of which are specific to MTB or MTB complex [28]. Out of which, four genes has been selected for our study considering their importance in the analysis of ethiopathogenesis and diagnosis of FGTB. In the present study, we report the efficacy of an amplification format based on the identification of the causative agents among highly suspected cases of FGTB in India at the genus $(32 \mathrm{kDa}$ protein/ MPT59 a (alpha)-antigen gene), MTB complex (MPB64 gene), regional specific MTB complex (TRC4 element) and species levels (19kDa antigen) in determining the tubercular aetiology of female infertility. Further, we have attempted to evaluate the diagnostic competence of multi-gene/ multi-primer PCR (multi-gene
PCR) vis-a`-vis laparoscopic findings, besides establishing the appropriateness of using multiple samples, namely endometrial tissue biopsies (ETBs), ovarian tissue biopsies (OTBs) and pelvic aspirated fluids (PAFs) for accurate diagnosis of FGTB.

\section{Statistical Analysis}

The sensitivity, specificity, positive predictive values and negatives predictive values were calculated using standard formulae [29] for diagnostic accuracy. Comparison of quantitative variables (age, age at menarche age, body mass index and duration of infertility among infertile women highly suspected with FGTB and control women) was performed by means of ANOVA analysis with the F-test using SPSS v 20 for Windows (IBM ${ }^{\circledR}$ SPSS ${ }^{\circledR}$ Statistics 20, Chicago, USA). The data was presented as mean \pm SD. Comparison among qualitative variables (menstrual irregularities, laparoscopic findings, types of biopsies and findings of conventional versus molecular methods among infertile women highly suspected with FGTB and control women) was performed by Pearson Chi-square test or Fisher's exact test or McNemar's test, as needed. The significant differences in the positive rate among different methods were analysed. Data were considered statistically significant if $p$ value was less than 0.05 .

\section{Ethical Approval}

The study protocol was in compliance with the Declaration of Helsinki, approved by the ethic committee of MHRT Hospital and Research Centre, Hyderabad in India. Informed consent was taken by our Institution through Ethical Committee because patient's samples were obtained by Operative Laparoscopy. In this case, we presented the letter before to begin the study.

\section{Materials and Methods}

A prospective case-control study was set in the Zoology Modular Lab, CFRD, Osmania University, Hyderabad, India. During the period of our study (2006-2014), the samples from infertile women visiting the gynaecology clinics at two collaborating centres in Hyderabad were analysed. All patients met the inclusion criteria i.e. 18-40 years of age having irregular periods with laparoscopic finding indicating beaded, blocked and tubal adhesions, infertility, pelvic pain, scanty menstruation, amenorrhoea and frozen pelvic and histopathological evidence in biopsy of premenstrual endometrial tissues or demonstration of tubercle bacilli in culture of menstrual blood or pelvic aspirated fluids or endometrial curetting. Exclusion criteria were the following: Women above 40 years of age, symptoms suggestive of pulmonary tuberculosis (TB)/ extra pulmonary TB except infertility, with normal abdominal and vaginal examinations, with pregnancy or nursing, severe psychiatric dysfunctions, endocrine problems, sexual disorders, multiple sclerosis or other autoimmune disorders, pulmonary infections, HIV coinfection, women with diabetes, malnutrition and other medical disorders like hypertension, peritoneal adhesions 
due to previous abdominal surgery, infertility due to male factors and abnormality in ovulations. Information on the general, obstetric and gynaecological details including family history, marital status, age at menarche, length of menstrual cycle, associated symptoms, duration and amount of blood loss, duration of infertility, and socio demographic details like social status, occupation, lifestyle, age, body mass index (BMI), limited information on diet were obtained. Apart from routine examinations, laparoscopy and hysteroscopy was performed for infertility workup as and when needed. All subjects were HIV negative and negative for pulmonary TB on the basis of complete history, physical examinations; chest X-ray, lung plain X-ray and by appropriate tests such as tuberculin test [19]. Details of hystero-laparoscopy findings like unilateral or bilateral tubal block with hydrosalphinx, omental adhesions, frozen pelvics, tuboovarian masses, tubercular salphingitis, beaded tubes and tubercles were noted. Beaded appearance of tubes, frank tubercules on uterus and pelvic mass in variable combination aroused a suspicion. Constitutional symptoms such as sweating, increase in temperature and weight loss were not major complaints while local organ dysfunction manifested in amenorrhea, omental adhesions and bilateral tubal blockage are seen on hysterosalpingographic study.

\subsection{Case Group}

A total of 302 specimens were taken for study which included 202 infertile women highly suspected of having genital tuberculosis on laparoscopic examination and 100 control women (without TB) of reproductive age. All samples collected were examined by $\mathrm{H}$ \& $\mathrm{E}$ staining [30,31,32], Z-N staining for AFB [32,33,34], cultured on L-J egg media $[34,35,36]$ and MTB specific multi-gene PCR method [17,18,29,37-46] by which FGTB was confirmed and correlated with laparoscopic findings.

Table 1. Socio-demographic details among infertile women highly suspected of FGTB and control women

\begin{tabular}{|c|c|c|c|c|}
\hline Characteristics & $\begin{array}{l}\text { Case-Control Group }(\mathrm{n}= \\
302)\end{array}$ & Mean \pm SD & F-test values on ANOVA & Test of significant (Values on ANOVA) \\
\hline \multirow{2}{*}{ Age (Years) } & Case $(n=202)$ & $28.54 \pm 4.46$ & \multirow{2}{*}{2.894} & \multirow{2}{*}{0.09} \\
\hline & Control $(\mathrm{n}=100)$ & $27.59 \pm 4.62$ & & \\
\hline \multirow{2}{*}{ Age at menarche (Years) } & Case $(n=202)$ & $12.49 \pm 1.02$ & \multirow{2}{*}{0.965} & \multirow{2}{*}{0.327} \\
\hline & Control $(n=100)$ & $12.37 \pm 0.93$ & & \\
\hline \multirow{2}{*}{ Body mass index $\left(\mathrm{kg} / \mathrm{m}^{2}\right)$} & Case $(n=202)$ & $24.36 \pm 1.47$ & \multirow{2}{*}{2.538} & \multirow{2}{*}{0.112} \\
\hline & Control $(n=100)$ & $24.05 \pm 1.68$ & & \\
\hline \multirow{2}{*}{ Duration of infertility (Years) } & Case $(n=202)$ & $3.92 \pm 3.03$ & \multirow{2}{*}{151.653} & \multirow{2}{*}{0.000} \\
\hline & Control $(n=100)$ & $\begin{array}{c}0.174 \pm \\
0.184\end{array}$ & & \\
\hline
\end{tabular}

Note: Data were considered statistically significant if p value was less than 0.05; Degree of freedom (df) was one (1) for all calculations; $\mathrm{n}$ : number of patients; \%: percentage; SD: Standard Deviation; Analysis of Variance (ANOVA); kg: kilogram; m: meters.

The diagnosis was done based on morphological [19] $3.92 \pm 3.03$ years, BMI was $24.36 \pm 1.47$ and the and molecular investigations. All specimens tested by conventional/ phenotypic methods were later compared with multi-gene PCR method using four sets of primers for detection of MTB in a single tube- single step reaction. M. tuberculosis (ATCC 35836) reference stain isolates provided by Dept of Microbiology, Nizam's Institute of Medical Sciences, Hyderabad (India) were used as controls in each assay. Out of 202 specimens taken for study, 123 (60.89\%) were ETBs, 68 (33.66\%) were OTBs and 11 (5.44\%) were PAFs. The mean age of the subjects was $28.54 \pm 4.46$ years, mean duration of infertility was difference had statistical significance with (F-test = 151.653, 1df, $\mathrm{p}<0.0001$ ) different parameters. Table 1 depicts the demographic variables of the infertile women and control women. The majority of patients (77.23\%) presented primary infertility, 46 (22.77\%) with secondary infertility and 69 (34.15\%) women experienced abortion (Table 2). Apart from infertility, 125 (61.88\%) patients had other menstrual complaints such as dysmenorrhoea in 94 (46.53\%) women and abdominal/ pelvic pain in 31 (15.34\%) women.

Table 2. Type of infertility among Case-Control groups

\begin{tabular}{|c|c|c|}
\hline Characteristics & Infertile women suspected of FGTB (n=202) [n (\%)] & Control group (n=100) [n (\%)] \\
\hline Primary infertility & $466(77.23)$ & 0 \\
\hline Secondary infertility & 0 & $100(100)$ \\
\hline Proven fertility & $68(33.66)$ & 0 \\
\hline Abortions & $52(25.74)$ & $90(90)$ \\
\hline
\end{tabular}

Note: \%: percentage; $n$ : number of patients.

63 (31.19\%) patients had menstrual irregularities such as oligomenorrhea (12.87\%), amenorrhea (8.91\%), general malaise (4.95\%) and menorrhagia (4.45\%) among infertile women highly suspected with FGTB. The difference had statistical significance with (Pearson $\chi 2=$ 67.565, 1df, Fisher's exact test value <0.0001; McNemar's test value $=0.720)$. Statistical analysis of menstrual problems among infertile women highly suspected with FGTB and control women were described in Table 3. All patients were negative for chest X-ray and 42 (20.79\%) patients were positive for Mantoux test. Erythrocyte sedimentation rate (ESR) was elevated in all the patients. All the patients were asymptomatic, resistant to all therapeutic treatments other than anti TB therapy. 
Table 3. Statistical analysis of menstrual problems among infertile women highly suspected of FGTB and Controls

\begin{tabular}{|c|c|c|c|c|c|}
\hline \multirow{2}{*}{ Symptoms } & \multirow{2}{*}{$\begin{array}{l}\text { Case-Control Group } \\
(\mathrm{n}=302)\end{array}$} & \multirow{2}{*}{ Observed Cases [n (\%)] } & \multirow{2}{*}{ Pearson Chi-Square Value } & \multicolumn{2}{|c|}{ Exact Significance (2-sided) Values } \\
\hline & & & & Fisher's Exact Test & McNemar's Test $^{\mathrm{a}}$ \\
\hline \multirow{2}{*}{ Dysmenorrhoea } & Case $(n=202)$ & $94(46.53)$ & \multirow{2}{*}{$67.565^{b}$} & \multirow{2}{*}{0.000} & \multirow{2}{*}{0.720} \\
\hline & Control $(n=100)$ & 0 & & & \\
\hline \multirow{2}{*}{ Abdomeninal pain } & Case $(n=202)$ & $31(15.34)$ & \multirow{2}{*}{$17.102^{c}$} & \multirow{2}{*}{0.000} & \multirow{2}{*}{0.000} \\
\hline & Control $(n=100)$ & 0 & & & \\
\hline \multirow{2}{*}{ Oligomenorrhea } & Case $(n=202)$ & $26(12.87)$ & \multirow{2}{*}{$7.508^{d}$} & \multirow{2}{*}{0.006} & \multirow{2}{*}{0.000} \\
\hline & Control $(n=100)$ & $3(3)$ & & & \\
\hline \multirow{2}{*}{ Amenorrhea } & Case $(\mathrm{n}=202)$ & $18(8.91)$ & \multirow{2}{*}{$9.476^{\mathrm{e}}$} & \multirow{2}{*}{0.001} & \multirow{2}{*}{0.000} \\
\hline & Control $(n=100)$ & 0 & & & \\
\hline \multirow{2}{*}{ General malaise } & Case $(n=202)$ & $10(4.95)$ & \multirow{2}{*}{$5.120^{\mathrm{f}}$} & \multirow{2}{*}{0.034} & \multirow{2}{*}{0.000} \\
\hline & Control $(n=100)$ & 0 & & & \\
\hline \multirow{2}{*}{ Menorrhagia } & Case $(n=202)$ & $9(4.45)$ & \multirow{2}{*}{$0.863^{g}$} & \multirow{2}{*}{0.415} & \multirow{2}{*}{0.000} \\
\hline & Control $(n=100)$ & $7(7)$ & & & \\
\hline
\end{tabular}

Note: Statistical analysis showed 0 cells (0.0\%) have expected count less than 5 among all methods, except for “f” 1 cell (25.0\%) has expected count less than 5 and the minimum expected count is 3.31. The minimum expected counts for different methods were different, as the minimum expected count for "b” is 31.13; “c” is 10.26; “d” is 9.60; “e” is 5.96 and “g” is 5.30. "a”: binomial distribution used. Degree of freedom (df) was one (1) for all calculations, \%: percentage; n: number of patients. Data were considered statistically significant if p value was less than 0.05 .

\subsection{Control Group}

A total of 100 specimens were collected control women of reproductive age (18-40 years). Of which 27 (27\%) were ETBs, 27 (27\%) were OTBs and 46 (46\%) were PAFs. Women who attended the same clinic for other gyaecological disorders, tubal sterilization and laparoscopy for menorrhagia were selected as controls. All the women in this group were asymptomatic with mean age of $27.59 \pm 4.62$ years, mean duration of infertility was $0.174 \pm 0.184$ years and BMI was $24.05 \pm 1.68$. Menstrual irregularities such as oligomenorrhoea (3\%) and mild menorrhagia (7\%) were seen in the control women. 13 patients were positive to Mantoux test. All patients were fertile, negative for chest X-ray and laparoscopically confirmed to be without FGTB.

\subsection{Processing of Tissue Biopsy}

The specimens (like ETBs, OTBs and PAFs) collected from the lesions over the endometrium, ovaries and pelvic were mixed with sterile normal saline, transported in sterile vials to the laboratory and processed as per standard protocols $[17,18,47,48,49,50]$. Whole specimens were washed with saline and centrifugation at $6000 \mathrm{rpm}$ for $10 \mathrm{~min}$ at $4^{\circ} \mathrm{C}$. Supernatant were discarded and the

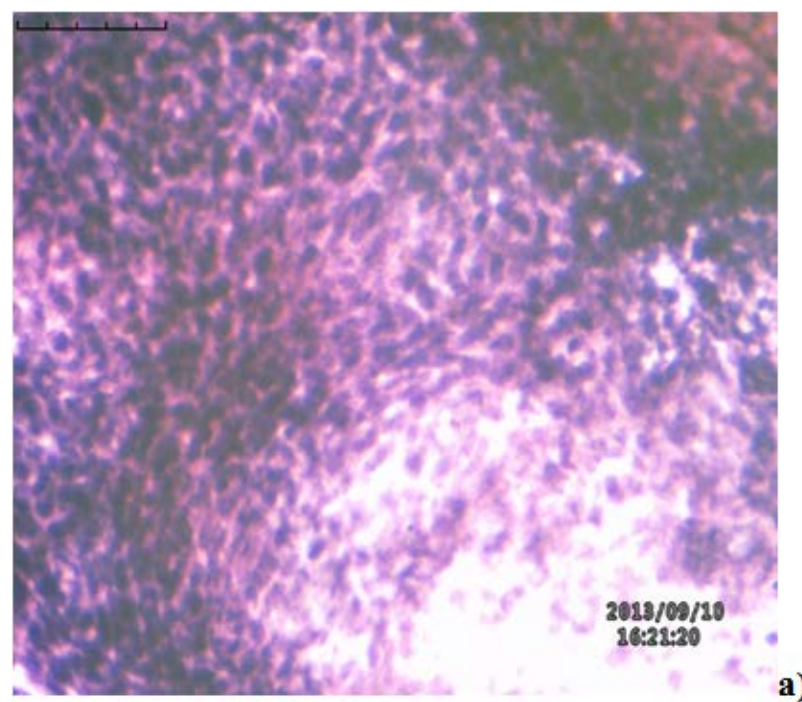

pellets were reconstituted with $1 \mathrm{ml}$ of sterile Tris Buffered Saline (1X TBS; pH-7.4). Each specimen (from TBS) was divided into two portions-one kept for decontamination and concentration for subsequent studies such as Z-N staining, culturing on L-J media and extraction of DNA for multi-gene PCR method, and the other portion kept was used for histopathology, RNA and protein extraction.

\subsection{Decontamination and Concentration (DC)}

All specimens were decontaminated and concentrated by modified HS-SH procedure [51]. About 200 $\mu$ l of tissue biopsies or scrapings were minced and grinded well using tissue homogenizer and mixed with $200 \mu \mathrm{l}$ of $7 \%(\mathrm{w} / \mathrm{v})$ $\mathrm{NaCl}$ and $200 \mu \mathrm{l}$ of $4 \%(\mathrm{w} / \mathrm{v}) \mathrm{NaOH}$ in a sterile eppendorf centrifuge tube. Then, the tubes were incubated at $37^{\circ} \mathrm{C}$ for $30 \mathrm{~min}$. The content was neutralized with sterile normal saline, to make the total volume to $2 \mathrm{ml}$. The mixture was mixed for 5 seconds and centrifuged at $12,000 \mathrm{rpm}$ for $15 \mathrm{~min}$ at $4^{\circ} \mathrm{C}$ using aerosol proof shields. The supernatant was discarded into a splash-proof container with a tuberculocidal solution and the pellet was resuspended in $200 \mu \mathrm{l}$ of sterile TBS buffer and mixed for 5 seconds. Homogenised tissue sediments were used for culturing on L-J medium, Z-N staining and for the isolation of mycobacterial DNA.

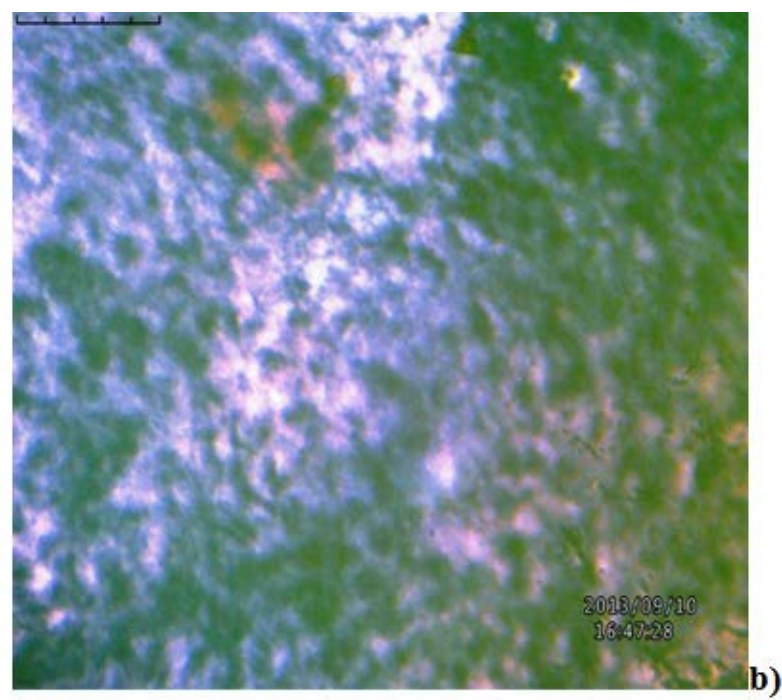

Figure 1. Histopathological Examination of Endo-ovarian Tissue Biopsy: a) Lymphocytic infiltrations and beaded cells were observed, b) Granulomatous cells were observed in endometrial tissue biopsies 


\subsection{Histopathological Examination}

Thin slices of the processed tissue biopsies and PAFs were placed onto the slides and kept for air drying at room temperature. Tissue specimens were fixed with buffered formalin (10\%), cleaned with xylene and dehydrated with absolute alcohol (100\%). The slides were again fixed with ethyl alcohol (95\%), washed with water and dried. Then, the slides were stained with Weigert's iron hematoxylin, washed with water, differentiated with acid alcohol (1\%) and alcohol (95\%) and washed with water. Followed by, the slides were counterstained with eosin [30,31,32], dehydrated with increasing gradients of alcohol, cleaned with xylene and mounted. Mounted slides were viewed under bright field (40x), Inverted Biological Microscope (BLM-290, BestScope, China). The presence of caseating granulomas surrounded by epitheloid cells, malignant lymphocytic infiltrations, beaded plasma cells and giant

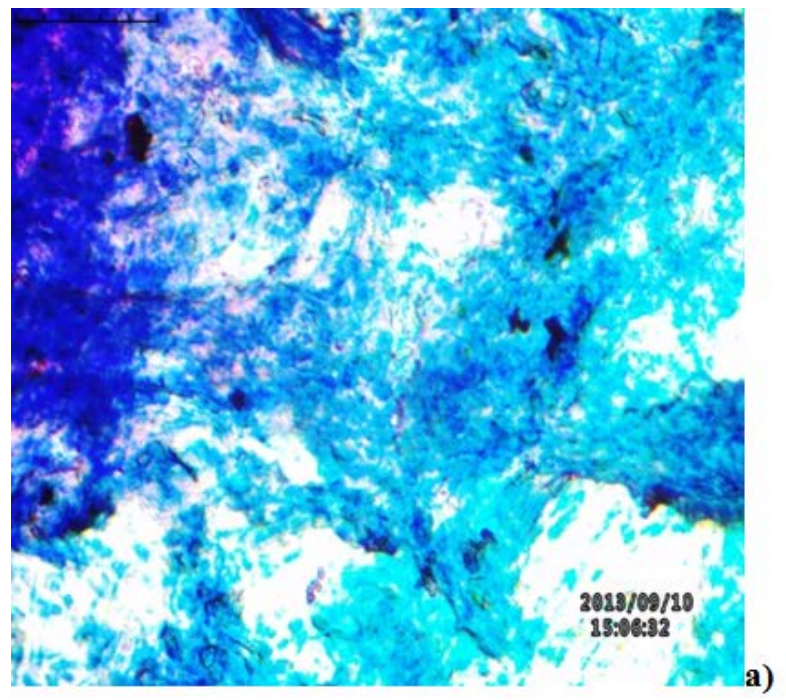

polymorphornuclear cells were diagnostic of FGTB (Figure 1).

\subsection{Ziehl-Neelson's (Z-N) Staining of Tissue Sediments for AFB}

For about $50 \mu \mathrm{l}$ of the decontaminated and concentrated endo-ovarian tissue sediments were spread onto the slides, kept air drying for 10 minutes at $60^{\circ} \mathrm{C}$ and heat-fixed for 10 minutes at $90^{\circ} \mathrm{C}$. The slides were then stained with carbolfuchsin, decolorized by acid alcohol and counterstained by methylene blue and rinsed with water to remove excess methylene blue. Stained slides were viewed under Inverted Biological Microscope. The portion of smear that stained pink/red on pale blue background was noted as Mycobacterium [32,33,34] (Figure 2).

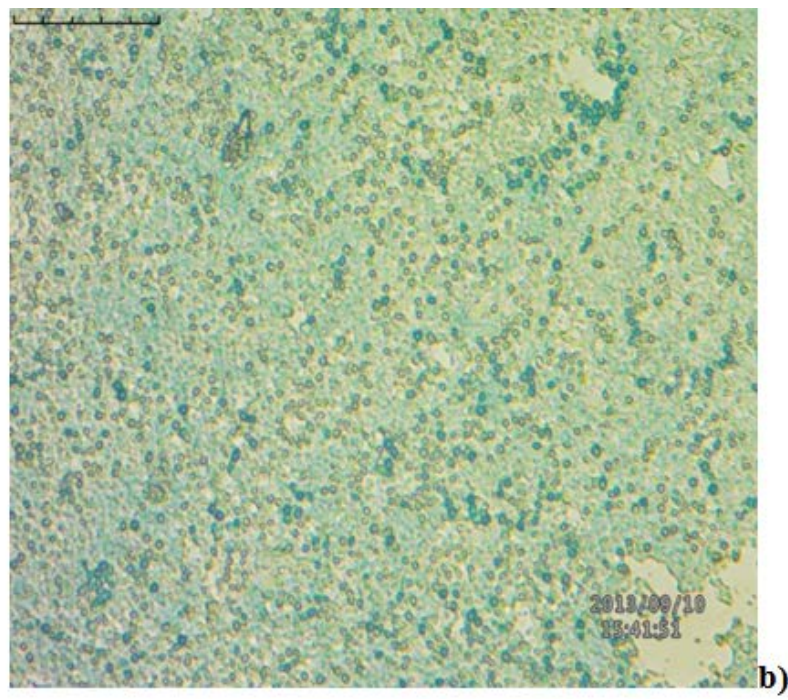

Figures 2. Z-N staining of Endo-ovarian Tissue Biopsy and Cultures for the detection of Acid fast bacilli (AFB): a) Pink/ Red colour rod like beaded structures were observed in the tissue biopsy; b) Pink/ Red colour rod like structures were observed on pale blue background in the cultures

\subsection{Culture of Tissue Sediments}

About $50 \mu \mathrm{l}$ inoculum of the decontaminated and concentrated endo-ovarian tissue biopsy sediments were taken and applied rapidly on L-J egg medium slants using sterile micropipette. Slant and bottled culture media were incubated in a horizontal plane until the inoculum was absorbed. The culture tubes were then incubated at $37^{\circ} \mathrm{C}$ for 6-8 weeks until heavy growth was obtained. Cultures were stained by $\mathrm{Z}-\mathrm{N}$ staining for confirmation of AFB growth [34,35]. Standard Precautions" [35,36] and Institutional guidelines have been followed in handling all items contaminated with blood and other body fluids.

\subsection{Quality Control}

Reagents were aliquoted and each aliquote was used only once. Sterile microcentrifuge tubes and PCR tubes were used for the PCR assay. Reagent preparation, DNA extraction, DNA amplification and detection were performed in separate rooms to avoid cross-contamination of amplicons. A positive control was included in each test and distilled water was included as a negative test control. The Clinical and Laboratory Standards Institute (CLSI, 2001 [36]) recommendations and regulations were followed for quality control and standards.

\subsection{DNA Extraction and Purification}

All the decontaminated and concentrated endo-ovarian tissue sediments were centrifuged at $8,000 \mathrm{~g}$ for 10 minutes and $180 \mu \mathrm{l}$ of $2 \mathrm{X}$ TE buffer ( $20 \mathrm{mM}$ Tris- $\mathrm{HCl}, 2$ mM EDTA, pH 8.0) containing 1\% sodium dodecyl sulfate $(40 \mu \mathrm{l}$ from $10 \%$ SDS), $2.4 \%$ Triton X-100 was added to the pellet for lysis of gram-positive bacteria [52], $20 \mathrm{mg} / \mathrm{ml}$ of lysozyme was subsequently added, mixed and incubated for $30-60 \mathrm{~min}$ at $37^{\circ} \mathrm{C}$. $25 \mu \mathrm{l}$ of Proteinase $\mathrm{K}$ $(20 \mathrm{mg} / \mathrm{ml})$ was added and mixed by vortexing and incubated in dry bath at $56^{\circ} \mathrm{C}$ for 1 to 3 hours until complete lysis was achieved (provided by DNASure @ Tissue mini kit from Genetix Biotech Asia Pvt. Ltd, New Delhi, India). Then, appropriate condition for binding of DNA to the silica membrane in the DNASure@ Tissue Mini Kit Columns was achieved by the addition of chaotropic salts and ethanol to the lysate. The binding process is reversible and specific to nucleic acids. Contaminations were removed by subsequent washing with two different buffers according to manufacturer instructions. Pure genomic DNA was finally eluted under low ionic strength conditions in a slightly alkaline elution buffer. The purity of DNA was checked on $0.8 \%$ agarose gel electrophoresis, incorporated with ethidium bromide. 
The bands in the gel were photographed under a Bio-Rad gel documentation system and quantified.

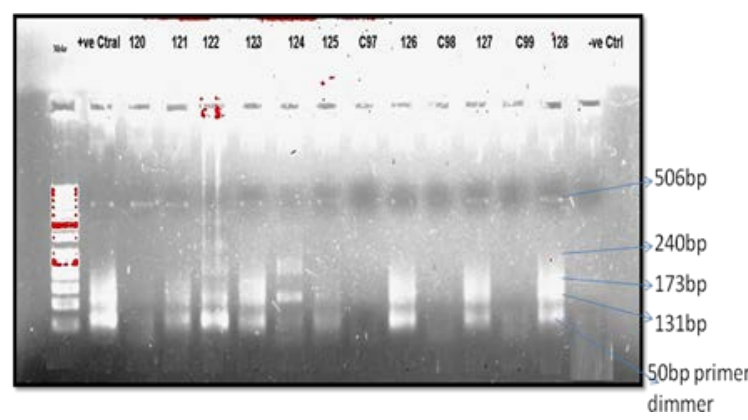

Figure 3: 2.5\% Agarose Gel Electrophoresis was carried out for Multigene/ Multi-primer PCR products: Lanes in the first row (120 to 128) were loaded with PCR products of FGTB patients; Lanes in the second row (C97 to C99) were loaded with PCR products of control patients; Lane +Ve Ctrl was loaded with positive Reference Strain ( $M$ tuberculosis, ATCC 35836); Lane -Ve Ctrl was loaded with negative control $\left(\mathrm{H}_{2} \mathrm{O}\right)$; Lane 50bp marker was loaded with 50 base pair (bp) molecular weight ladder (50bp size of product starts from the bottom side of gel and ends with 650bp product on the top/upper side of the gel), The band corresponding to $131 \mathrm{bp}$ was noted as $19 \mathrm{kDa}$ antigen gene, 173bp was noted as TRC4 element, 240bp was noted as MPB64 gene, 506bp was noted as 32kDa protein/ MPT59 $\alpha$ - antigen gene. Primer dimmers were also noted at the bottom during the end of sample run

\subsection{Multi-gene/ Multi-primer PCR Method}

Multi-gene PCR was performed with 20-30ng extracted DNA, and DNA amplification with 5U Taq DNA polymerase (Bangalore Genie, Bangalore, India), $10 \mathrm{mM}$ deoxyribonucleoside triphosphates (Bangalore Genie, Bangalore, India) and 13.5 pmol each primer (Bioserve Biotechnologies (India) Pvt Ltd, Hyderabad, AP, India) in a final volume of $50 \mu \mathrm{L}$. Two looped touchdown multigene PCR program; each with 25 cycles was followed. In the first loop, the template DNA was initially denatured at $95^{\circ} \mathrm{C}$ for 5 minutes then denatured at $94^{\circ} \mathrm{C}$ for 45 seconds, annealed at $68^{\circ} \mathrm{C}$ for 45 seconds, extended at $72^{\circ} \mathrm{C}$ for 45 seconds and continued for total of 25 cycles. In $2^{\text {nd }}$ loop; DNA was denatured at $94^{\circ} \mathrm{C}$ for 45 seconds, annealed at $58^{\circ} \mathrm{C}$ for 45 seconds, extended at $72^{\circ} \mathrm{C}$ for 45 seconds and continued for total of 25 cycles with final extension at $72^{\circ} \mathrm{C}$ for 15 minutes. The PCR amplification was done using master cycler gradient PCR system (Eppendorf, Hamburg, Germany). PCR products were subjected to electrophoresis in a $2.5 \%$ agarose gel incorporated with ethidium bromide, along with Gene Rule 50bp DNA ladder/ molecular weight marker. The electrophoresis was carried out at a constant voltage $(110 \mathrm{~V})$ for one hour. The bands in the gel were photographed under a Gel Doc-XRT with image lab software (Molecular Image, Bio-Rad, Hercules, CA, United States of America). The results of case-control group were compared with reference strain (Figure 3).

\section{Results}

There were no particular gold standard methods followed for the detection of FGTB. However, one should use varied combinations of tests to overcome the limitations such as the false positivity by way of contaminations, false negativity and dead bacilli or past infection or asymptomatic TB at another site. Even technical considerations, such as the use of suitable controls, standard strains and the retesting of doubtful positive samples, considerably influence the sensitivity and specificity. Therefore, this investigation has been conducted meticulously with appropriate controls, replications, large sample size and with different combination of experiments. The present study assesses the role of multi-gene PCR in the diagnosis of FGTB using ETBs, OTBs and PAF samples and correlated with laparoscopic findings. Primer selection of present study was done based on local characteristics of strains and their importance in the diagnosis of the disease (tabulated in Table 4). The nucleotide sequences of primers used for the detection of Mycobacterium in this study were described and validated as diagnostic markers in the past [17,18,29,37-46].

Table 4. Details of genes of Mycobacterium tuberculosis Complex

\begin{tabular}{|c|c|c|c|c|c|c|c|c|}
\hline S.No & Gene & $\begin{array}{c}\text { Forward } \\
\text { primer }\end{array}$ & $\begin{array}{l}\text { Reverse } \\
\text { primer }\end{array}$ & $\begin{array}{l}\text { Length } \\
\text { \& Size } \\
\text { (bp) }\end{array}$ & $\begin{array}{l}\text { Reported } \\
\text { annealing } \\
\text { temp. }\end{array}$ & Function & Conclusion & Ref. \\
\hline 1 & $\begin{array}{l}19 \text { kDa } \\
\text { Antigen } \\
\text { gene }\end{array}$ & $\begin{array}{l}\text { 5'TCTTT } \\
\text { CCGGA } \\
\text { TGTTCA } \\
\text { AGCA 3' }\end{array}$ & $\begin{array}{l}\text { 5'TGAC } \\
\text { GTTCTG } \\
\text { GTCCTT } \\
\text { ACC3' }\end{array}$ & $20 ; 131$ & 58,68 & $\begin{array}{l}\text { It acts as an antigen for } \\
\text { cellular and humoral arms } \\
\text { of the adaptive response. } \\
\text { Involved in suppression of } \\
\text { growth and apoptosis of } \\
\text { infected cells. }\end{array}$ & $\begin{array}{c}\text { Secreted nature can } \\
\text { contribute to its serological } \\
\text { immunodominance by } \\
\text { enhancing its accessibility in } \\
\text { a native form for B-cell } \\
\text { recognition. }\end{array}$ & 37,38 \\
\hline 2 & $\begin{array}{c}\text { TRC4 } \\
\text { Element }\end{array}$ & $\begin{array}{l}\text { 5'GACA } \\
\text { ACGAC } \\
\text { GTGCG } \\
\text { CCTACT } \\
\text { 3' } \\
\end{array}$ & $\begin{array}{l}\text { 5'GACC } \\
\text { GAATT } \\
\text { AGCGT } \\
\text { AGCTC } \\
\text { C 3' }\end{array}$ & $20 ; 173$ & 57,58 & $\begin{array}{l}\text { It is from a very essential } \\
\text { region of } M \text {. tuberculosis } \\
\text { genome participating in } \\
\text { recombination }\end{array}$ & $\begin{array}{l}\text { Ideal target for PCR assays to } \\
\text { identify } M \text {. tuberculosis; } \\
\text { especially in strains carrying } \\
\text { no copies of IS6110 in extra } \\
\text { pulmonary patients }\end{array}$ & $\begin{array}{c}18,39, \\
40\end{array}$ \\
\hline 3 & $\begin{array}{l}\text { MPB64 } \\
\text { Antigen } \\
\text { gene }\end{array}$ & $\begin{array}{l}\text { 5’TCCG } \\
\text { CTGCC } \\
\text { AGTCG } \\
\text { TCTTCC } \\
\text { 3' }\end{array}$ & $\begin{array}{l}\text { 5’GTCC } \\
\text { TCGCG } \\
\text { AGTCT } \\
\text { AGGCC } \\
\text { A 3' }\end{array}$ & $20 ; 240$ & 55,60 & $\begin{array}{c}\text { Highly immunogenic } \\
\text { antigen and found in active } \\
\text { cultures }\end{array}$ & $\begin{array}{c}\text { This polymeric epitopes can } \\
\text { be a good candidates for } \\
\text { serodiagnosis }\end{array}$ & $\begin{array}{c}17,29, \\
41\end{array}$ \\
\hline 4 & $\begin{array}{l}\text { 32kDa } \\
\text { Protein }\end{array}$ & $\begin{array}{l}\text { 5’TTCC } \\
\text { TGACC } \\
\text { AGCGA } \\
\text { GCTGC } \\
\text { CG 3' }\end{array}$ & $\begin{array}{l}\text { 5’CCCC } \\
\text { AGTAC } \\
\text { TCCCA } \\
\text { GCTGT } \\
\text { GC 3' }\end{array}$ & $21 ; 506$ & 68,71 & $\begin{array}{l}\text { Abundantly secreted, } \\
\text { catalyses in formation of } \\
\text { mycobacterial cell wall } \\
\text { assembly }\end{array}$ & $\begin{array}{c}\text { This antigen would provide a } \\
\text { target, which is universally } \\
\text { present. }\end{array}$ & $42-46$ \\
\hline
\end{tabular}

T: thymine; A: adenine; G: guanine; $\mathrm{C}$ : cytosine 
None of the patients in our study reported family history of tuberculosis. Laparoscopy usually detects macroscopic changes such as peritubal adhesions, tubercles on the tubes and small tubo-ovarian masses that are commonly seen in chronic cases. FGTB also presents distinctive diagnostic challenges including subtle clinical manifestations that were over looked in laparoscopy during early stages of infection [8]. Clinical presentations such as dysmenorrhoea in 94 (46.53\%) women, beaded tubes in 139 (68.81\%) women, tubal block with hydrosalphinx in 119 (58.91\%), tubercular salpingitis in 97 (48.01\%), omental adhesions in 78 (38.61\%) and multiple tubercules in 72 (35.64\%) women were recorded in the case group. Only thicken tubes and tubal adhesions were observed in 4 (4\%) control women varied clinical presentations among infertile women with FGTB were significantly dissimilar from that of the control women (Pearson $\chi^{2}=97.219$, 1df, Fisher's exact test value $<0.0001)$. The difference was due to over representations

Table 5. Laparoscopic findings and their statistical association with infertile women highly suspected of FGTB and Controls

\begin{tabular}{|c|c|c|c|c|c|}
\hline \multirow{2}{*}{ Clinical Symptoms } & \multirow{2}{*}{$\begin{array}{l}\text { Case-Control Group (n } \\
=302 \text { ) }\end{array}$} & \multirow{2}{*}{$\begin{array}{l}\text { Observed Cases [n } \\
(\%)]\end{array}$} & \multirow{2}{*}{$\begin{array}{l}\text { Pearson Chi- } \\
\text { Square Value }\end{array}$} & \multicolumn{2}{|c|}{ Exact Significance (2-sided) Values } \\
\hline & & & & Fisher's Exact Test & McNemar's Test $^{1}$ \\
\hline \multirow{2}{*}{$\begin{array}{l}\text { Tubal block with } \\
\text { hydrosalphinx }\end{array}$} & Case $(n=202)$ & $119(58.91)$ & \multirow{2}{*}{$97.219^{\mathrm{a}}$} & \multirow{2}{*}{0.000} & \multirow{2}{*}{0.224} \\
\hline & Control $(n=100)$ & 0 & & & \\
\hline \multirow{2}{*}{ Tubo-ovarian mass } & Case $(n=202)$ & $59(29.21)$ & \multirow{2}{*}{$36.300^{\mathrm{b}}$} & \multirow{2}{*}{0.000} & \multirow{2}{*}{0.001} \\
\hline & Control $(\mathrm{n}=100)$ & 0 & & & \\
\hline \multirow{2}{*}{ Tubercular salphingitis } & Case $(n=202)$ & $97(48.01)$ & \multirow{2}{*}{$70.741^{\mathrm{c}}$} & \multirow{2}{*}{0.000} & \multirow{2}{*}{0.887} \\
\hline & Control $(n=100)$ & 0 & & & \\
\hline \multirow{2}{*}{ Beaded tubes } & Case $(n=202)$ & $139(68.81)$ & \multirow{2}{*}{$127.492^{\mathrm{d}}$} & \multirow{2}{*}{0.000} & \multirow{2}{*}{0.014} \\
\hline & Control $(n=100)$ & 0 & & & \\
\hline \multirow{2}{*}{ Bilateral opening of tubes } & Case $(\mathrm{n}=202)$ & $50(24.75)$ & \multirow{2}{*}{$29.664^{\mathrm{e}}$} & \multirow{2}{*}{0.000} & \multirow{2}{*}{0.000} \\
\hline & Control $(n=100)$ & 0 & & & \\
\hline \multirow{2}{*}{$\begin{array}{c}\text { Thicken tubes \& Tubal } \\
\text { adhesions }\end{array}$} & Case $(n=202)$ & 34 (16.83) & \multirow{2}{*}{$10.012^{\mathrm{f}}$} & \multirow{2}{*}{0.001} & \multirow{2}{*}{0.000} \\
\hline & Control $(n=100)$ & $4(4)$ & & & \\
\hline \multirow{2}{*}{ Tubercules on uterus } & Case $(n=202)$ & $19(9.4)$ & \multirow{2}{*}{$10.037^{\mathrm{g}}$} & \multirow{2}{*}{0.001} & \multirow{2}{*}{0.000} \\
\hline & Control $(n=100)$ & 0 & & & \\
\hline \multirow{2}{*}{ Omental adhesions } & Case $(n=202)$ & 78 (38.61) & $50 \Omega 0^{\mathrm{h}}$ & & \\
\hline & Control $(n=100)$ & 0 & 52.000 & 0.000 & 0.110 \\
\hline Гиотоn nluic & Case $(n=202)$ & 55 (27.23) & $22001^{\mathrm{i}}$ & 0000 & 0000 \\
\hline rTOzeIr pervis & Control $(n=100)$ & 0 & 33.291 & 0.000 & 0.000 \\
\hline Multinlo tuborculoc & Case $(n=202)$ & 72 (35.64) & $16000^{\mathrm{j}}$ & 0000 & 0030 \\
\hline 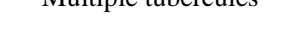 & Control $(n=100)$ & 0 & 40.002 & 0.000 & 0.053 \\
\hline Small ovaries and lower & Case $(n=202)$ & 37 (18.31) & $20074 \mathrm{k}$ & 0000 & 0000 \\
\hline abdominal mass & Control (n = 100) & 0 & $20.0 / 4$ & 0.000 & 0.000 \\
\hline
\end{tabular}

Note: \%: percentage; n: number of patients; statistical analysis showed 0 cells (0.0\%) have expected count less than 5 for all methods. The minimum expected count for different methods were different, as the minimum expected count for "a” is 39.40; "b” is 19.54; “c” is 32.12; "d" is 46.03; "e" is 16.56 ; “f” is 12.58; "g” is 6.29; " $h$ ” is 25.83; "i" is 18.21; “j” is 23.84 and " $k$ ” is 12.25; "l” denotes binomial distribution used. Degree of freedom (df) was one (1) for all calculations. Data were considered statistically significant if p value was less than 0.05.

Out of 85 cultures positive cases, 81 (26.82\%) FGTB cases were found AFB positive by Ziehl-Neelson's (Z-N) staining. All control women $(n=100)$ were found negative for tuberculosis with endometrium, ovaries and pelvics. Disparity among detection of FGTB by Z-N staining for AFB positive, histopathological evidence of tuberculosis infection, isolation by culture, and detection of M. tuberculosis complex by multi-gene PCR within infertile women highly suspected of genital TB and (Pearson $\chi 2=127.492,1 \mathrm{df}$, McNemar's test value $=0$. 014). Table 5 shows varied clinical variables among infertile women with FGTB and control women. A standard protocol of investigations revealed a number of causes for fertility deprivation. The multi-gene PCR detection rate for the disease was the highest of all the other tests as it detected, 178 (58.94\%) out of the 302 endo-ovarian tissue specimens, 104 (34.43\%) specimens collected from infertile women and 1 (0.33\%) ETB from control woman was positive on hematoxylin and eosin $(\mathrm{H}$ \& E) staining (Pearson $\chi 2=75.167,1 d$, Fisher's exact test value $<0.0001$, McNemar's test value $=0.779$ ) $[17,18]$. Acid fast bacilli (AFB) were positive in 44 (14.57\%) decontamination and concentration (DC) tissue specimens collected from infertile women and 1 (0.33\%) OTB from control woman was positive by cultivation on Lo“*wenstein-Jensen (L-J) egg media. of clinical symptoms in infertile women with FGTB 
Table 6. Statistical analysis and validation of the results obtained by conventional verses molecular methods among case-control groups (n=302)

\begin{tabular}{|c|c|c|c|c|c|}
\hline \multirow{2}{*}{$\begin{array}{l}\text { Conventional verses Molecular } \\
\text { Methods }\end{array}$} & \multirow{2}{*}{$\begin{array}{l}\text { Case-Control } \\
\text { Group }(\mathrm{n}=302)\end{array}$} & \multirow{2}{*}{$\begin{array}{l}\text { Observed Cases [n } \\
(\%)]\end{array}$} & \multirow{2}{*}{$\begin{array}{l}\text { Pearson Chi-Square } \\
\text { Value }\end{array}$} & \multicolumn{2}{|c|}{ Exact Significance (2-sided) Values } \\
\hline & & & & Fisher's Exact Test & McNemar's Test ${ }^{\mathrm{a}}$ \\
\hline \multirow{2}{*}{ H \& E Staining } & Case $(n=202)$ & $104(51.48)$ & \multirow{2}{*}{$75.167^{\mathrm{b}}$} & \multirow{2}{*}{0.000} & \multirow{2}{*}{0.779} \\
\hline & Control $(\mathrm{n}=100)$ & $1(1)$ & & & \\
\hline \multirow{2}{*}{$\begin{array}{l}\text { AFB +Ve on Z-N Staining of } \\
\text { tissue sediments }\end{array}$} & Case $(n=202)$ & $44(21.78)$ & \multirow{2}{*}{$25.497^{\mathrm{c}}$} & \multirow{2}{*}{0.000} & \multirow{2}{*}{0.000} \\
\hline & Control $(\mathrm{n}=100)$ & 0 & & & \\
\hline \multirow{2}{*}{ L-J Egg medium } & Case $(n=202)$ & $85(42.08)$ & \multirow{2}{*}{$55.418^{\mathrm{d}}$} & \multirow{2}{*}{0.000} & \multirow{2}{*}{0.338} \\
\hline & Control $(\mathrm{n}=100)$ & $1(1)$ & & & \\
\hline \multirow{2}{*}{$\begin{array}{c}\text { AFB +Ve on Z-N Staining of } \\
\text { culture }\end{array}$} & Case $(\mathrm{n}=202)$ & $81(40.1)$ & \multirow{2}{*}{$55.725^{\mathrm{e}}$} & \multirow{2}{*}{0.000} & \multirow{2}{*}{0.208} \\
\hline & Control $(\mathrm{n}=100)$ & 0 & & & \\
\hline \multirow{2}{*}{ 19kDa (131bp) } & Case $(\mathrm{n}=202)$ & $175(86.63)$ & \multirow{2}{*}{$206.011^{\mathrm{f}}$} & \multirow{2}{*}{0.000} & \multirow{2}{*}{0.000} \\
\hline & Control $(n=100)$ & 0 & & & \\
\hline \multirow{2}{*}{ TRC4 (173bp) } & Case $(\mathrm{n}=202)$ & $175(86.63)$ & \multirow{2}{*}{$206.011^{\mathrm{g}}$} & \multirow{2}{*}{0.000} & \multirow{2}{*}{0.000} \\
\hline & Control $(n=100)$ & 0 & & & \\
\hline \multirow{2}{*}{ MPB64 (240bp) } & Case $(n=202)$ & $142(70.3)$ & \multirow{2}{*}{$132.686^{\mathrm{h}}$} & \multirow{2}{*}{0.000} & \multirow{2}{*}{0.008} \\
\hline & Control $(n=100)$ & 0 & & & \\
\hline \multirow{2}{*}{ 32kDa (506bp) } & Case $(\mathrm{n}=202)$ & $178(88.12)$ & \multirow{2}{*}{$214.612^{\mathrm{i}}$} & \multirow{2}{*}{0.000} & \multirow{2}{*}{0.000} \\
\hline & Control $(\mathrm{n}=100)$ & 0 & & & \\
\hline
\end{tabular}

Note: "a" denotes binomial distribution used. Statistical analysis showed 0 cells $(0.0 \%)$ have expected count less than 5 for all methods. The minimum expected counts for different methods were different, as the minimum expected count for "b" is 34.77; "c" is 14.57 ; " $\mathrm{d}$ ” is 28.48 ; "e" is 27.15 ; “f” is 42.05; "g" is 42.05; "h" is 47.02; and "i" is 41.06. Degree of freedom (df) was one (1) for all calculations. Data were considered statistically significant if p value was less than 0.05. Some patients had more than one abnormal finding; n: number of patients; \%: percentage. Abbreviations: Female Genital Tuberculosis (FGTB); Endometrial tissue biopsies (ETBs); Ovarian tissue biopsies (OTBs); Pelvic aspirated fluids (PAFs); Hematoxylin and Eosin (H \& E) staining; Lowenstein Jensen (L-J) Egg medium; AFB +Ve, Acid fast bacilli positive; Ziehl-Neelson's (Z-N) staining; Polymerase Chain Reaction (PCR); 19kDa antigen gene: 19kDa (131bp); TRC4 element: TRC4 (173bp); MPB64 antigen gene: MPB64 (240bp); $32 \mathrm{kDa}$ protein (MTP-59 $\alpha$-antigen) gene: $32 \mathrm{kDa}(506 \mathrm{bp})$.

Of the 68 (33.66\%) OTBs, 42 (20.79\%) were positive with H \& E staining, 41 (20.29\%) by culturing on L-J egg medium and 39 (19.3\%) were AFB positive with Z-N staining of culture. Subsequently, 67 (33.17\%) were positive for $19 \mathrm{kDa}$ antigen (131bp) gene and $32 \mathrm{kDa}$ protein (506bp) gene by multi-gene PCR. Present study also reports, 5 (2.47\%) out of $11(5.44 \%)$ PAFs, were positive with $\mathrm{H}$ \& E staining, 7 (3.46\%) were positive on L-J egg medium and with Z-N staining after culturing. 11 (5.44\%) samples were positive for 19kDa antigen (131bp) gene and 32kDa protein (506bp) gene by multi-gene PCR

highly suspected cases of FGTB, 175 (86.63\%) specimens were positive for $19 \mathrm{kDa}$ antigen (131bp) gene (MTB species-specific gene) and TRC4 (173bp) repetitive element (south Indian MTB complex specific). 142 (70.3\%) specimens were positive for MPB64 antigen (240bp) gene (MTB complex specific). 178 (88.12\%) endo-ovarian tissue biopsies and pelvic aspirated fluid specimens were positive for 32kDa protein (506bp) gene by multi-gene PCR method (Pearson $\chi^{2}=214.612$, $1 \mathrm{df}$, Fisher's exact test value $<0.0001$, McNemar's test value $<0.0001)$. (Table 7). Amongst, the 202 specimens collected from

Table 7. Type of samples and findings of conventional versus molecular methods among infertile women suspected of FGTB and Controls

\begin{tabular}{|c|c|c|c|c|c|c|c|c|c|}
\hline & & & \multicolumn{3}{|c|}{ Conventional/ Phenotypic methods } & \multicolumn{3}{|c|}{ Molecular method (Multi-gene/ multi- } \\
primer PCR)
\end{tabular}

Note: Some patients had more than one abnormal finding; n: number of patients; \%: percentage; NA: not applicable. Abbreviations: Endometrial tissue biopsies (ETBs), Ovarian tissue biopsies (OTBs), Pelvic aspirated fluids (PAFs).

The conventional methods showed $99 \%$ to $100 \%$ specificity with a low sensitivity, ranging from $21.78 \%$ to 42.08\% while $\mathrm{H} \& \mathrm{E}$ staining showed a sensitivity of $51.48 \%$. However, multi-gene PCR method was found to have a much higher sensitivity of $70.29 \%$ for MTB64 gene, $86.63 \%$ for $19 \mathrm{kDa}$ antigen gene and TRC4 element and $88.12 \%$ for $32 \mathrm{kDa}$ protein gene [43,53]. The specificity of multi-gene PCR was $100 \%$ (tabulated in Table 8). The conventional/ phenotypic methods had $98.83 \%$ to $100 \%$ positive predictive value with a lower 
negative predictive value, ranging from $38.75 \%$ to $45.83 \%$ whereas $\mathrm{H} \& \mathrm{E}$ staining had a negative predictive value of 50.25\%. Multi-gene PCR method was found to have much varied negative predictive value of $62.5 \%$ with MTB64 gene, $78.74 \%$ with $19 \mathrm{kDa}$ antigen gene and TRC4 element and $80.64 \%$ with $32 \mathrm{kDa}$ protein gene. The positive predictive value of multi-gene PCR was $100 \%$. Of four different methods used, histopathology and culture on L-J egg media showed false positive in 1 (0.33\%) tissue sediment. On other side, 24 (7.95\%) specimens showed false negative with $32 \mathrm{kDa}$ protein (506bp) gene and 27 (8.94\%) tissue specimens were false negative with $19 \mathrm{kDa}$ antigen (131bp) gene and TRC4 (173bp) element and 60 (19.86\%) with MPB64 antigen (240bp) gene by multigene PCR method. 98 (32.45\%) tissue specimens were false negative by $\mathrm{H}$ \& E staining, 158 (52.31\%) tissue sediments were false negative by Z-N staining, 117 (38.74\%) specimens were false negative with cultures on L-J egg medium and 121 (40.06\%) cultures were false negative by Z-N staining. All false negative samples evidenced by every conventional and molecular methods were likely to represent negative for tuberculosis as multigene PCR was repeatedly proven negative even though, they belongs to highly suspected cases of FGTB on laparoscopic examination. In the non TB control group, all the tests were negative for TB. These results showed that the molecular method is more accurate than the conventional methods $[17,18,29]$.

\section{Discussion}

Female genital tuberculosis is an important cause of infertility and may simulate advanced ovarian malignancy [54]. It is an indefinable diagnosis and a high index of suspicion is very essential in the routine diagnostic process. However laparoscopy is invasive, expensive procedure by which absolute diagnosis of FGTB cannot be made, although laparoscopy can pick up the signs of disease and provides an opportunity to take samples for laboratory investigations from various suspicious sites [20,21]. Several PCR techniques have been developed for the direct detection of $M$. tuberculosis $[17,18,43,55]$ and for the detection of Mycobacterium spp [43,45,56]. However, PCR using single target gene alone is not sufficient in the detection of all strains of M. tuberculosis, therefore use of multiple target genes is more appropriate $[29,39]$.

Table 8. Comparison of Specificity and Sensitivity among methods $(n=302)$

\begin{tabular}{|c|c|c|c|c|c|c|c|c|}
\hline $\begin{array}{l}\text { Methods versus } \\
\text { Characteristics }\end{array}$ & $\begin{array}{c}\text { True } \\
\text { Negatives } \\
{[n(\%)]} \\
\end{array}$ & $\begin{array}{c}\text { False } \\
\text { Positives } \\
\text { [n (\%)] } \\
\end{array}$ & $\begin{array}{c}\text { True } \\
\text { Positive [n } \\
(\%)] \\
\end{array}$ & $\begin{array}{c}\text { False } \\
\text { Negatives } \\
{[n(\%)]} \\
\end{array}$ & $\begin{array}{c}\text { Positive } \\
\text { Predictive } \\
\text { Value (\%) } \\
\end{array}$ & $\begin{array}{l}\text { Negative } \\
\text { Predictive } \\
\text { Value (\%) } \\
\end{array}$ & $\begin{array}{l}\text { Sensitivity } \\
\text { (\%) }\end{array}$ & $\begin{array}{l}\text { Specificity } \\
(\%)\end{array}$ \\
\hline $\begin{array}{l}\text { PCR for } 19 \text { kDa } \\
\text { Antigen (131bp) }\end{array}$ & $100(33.11)$ & 0 & 175 (57.95) & 27 (8.94) & 100 & 78.74 & 86.63 & 100 \\
\hline $\begin{array}{l}\text { PCR for TRC4 } \\
\text { Element (173bp) }\end{array}$ & $100(33.11)$ & 0 & 175 (57.95) & 27 (8.94) & 100 & 78.74 & 86.63 & 100 \\
\hline $\begin{array}{l}\text { PCR for MPB64 } \\
\text { Antigen (240bp) } \\
\end{array}$ & $100(33.11)$ & 0 & $142(47.02)$ & $60(19.86)$ & 100 & 62.5 & 70.29 & 100 \\
\hline $\begin{array}{c}\text { PCR for 32kDa } \\
\text { Protein/MPT59 } \alpha \text { - } \\
\text { Antigen (506bp) }\end{array}$ & $100(33.11)$ & 0 & 178 (58.94) & 24 (7.95) & 100 & 80.64 & 88.12 & 100 \\
\hline $\begin{array}{c}\text { H \& E Staining of } \\
\text { endo-ovarian tissue } \\
\text { biopsy }\end{array}$ & 99 (32.78) & $1(0.33)$ & $104(34.43)$ & 98 (32.45) & 99.04 & 50.25 & 51.48 & 99 \\
\hline $\begin{array}{c}\text { Z-N Staining of tissue } \\
\text { sediment }\end{array}$ & $100(33.11)$ & 0 & 44 (14.57) & 158 (52.31) & 100 & 38.75 & 21.78 & 100 \\
\hline $\begin{array}{c}\begin{array}{c}\text { Growth on L-J Egg } \\
\text { medium }\end{array} \\
\end{array}$ & 99 (32.78) & $1(0.33)$ & 85 (28.14) & 117 (38.74) & 98.83 & 45.83 & 42.08 & 99 \\
\hline $\begin{array}{l}\text { AFB Z-N Staining of } \\
\text { culture }\end{array}$ & 100 (33.11) & 0 & $81(26.82)$ & $121(40.06)$ & 100 & 45.24 & 40.1 & 100 \\
\hline
\end{tabular}

Note: Some patients had more than one abnormal finding; n: number of patients; \%: percentage. Abbreviations: Multi-gene/ multi-primer Polymerase Chain Reaction (Multi-gene PCR), Hematoxylin and Eosin (H \& E) Staining, Ziehl-Neelsen (Z-N) Staining, Growth on Lo“wenstein-Jensen (L-J) Egg medium. The following terms were described based on socio-demographic details, clinical and hysteroscopic/ laparoscopic findings of infertile women highly suspected of female genital tuberculosis (FGTB) and control women (without tuberculosis): True Negatives: 19kDa antigen (131bp) gene negative/ TRC4 (173bp) element negative/ MPB64 (240bp) gene negative/ 32kDa protein (MTP-59 $\alpha$-antigen; 506bp) gene negative on multi-gene/ multi-primer PCR method or H \& E staining negative/ AFB negative on Z-N staining/ absence of growth on L-J egg media/ without TB/ remains fertile/ healthy/ absence of abnormal clinical findings on laparoscopic examination; True Positive: 19kDa antigen (131bp) gene positive/ TRC4 (173bp) element positive/ MPB64 (240bp) gene positive/ 32kDa protein (MTP-59 $\alpha$-antigen; 506bp) gene positive on multi-gene/ multi-primer PCR method or H \& E staining positive/ AFB positive on Z-N staining/ presence of growth on L-J egg medium/ highly suspected of FGTB/ remains infertile/ presence of abnormal clinical findings on hysteroscopic/ laparoscopic examination; False positive: Multi-gene/ Multi-primer PCR positive or Conventional/ phenotypic methods positive among negative TB patients (control) group/ remains fertile/ healthy/ laparoscopically negative clinical findings; False negative: Multi-gene/ Multi-primer PCR or Conventional/ Phenotypic methods negative among women with highly suspected of FGTB/ remains infertile/ women with abnormal clinical findings on hysteroscopic/ laparoscopic examination.

It has great potential in the laboratory diagnosis of FGTB, particularly in latent and paucibacillary conditions as well as in active tuberculosis. Improvement in the sensitivity of PCR was reported by using different set of targets in the detection of extrapulmonary tuberculosis [39,40,44]. The increase in PCR sensitivity and decrease in false negative results was achieved using dual targets for the detection of $M$. tuberculosis [53]. Furthermore, the high endemicity of TB in India raises the possibility of this patient harbouring a latent infection. A broad range of mycobacterial species are involved in causing such

infections, but the type of complexes, species or type of strains that causes disease are not clear. Identification of nontuberculous Mycobacterium and treatments based on inconclusive findings involving different strains may not be adequate to control the disease. Therefore, this prospective large case-control cohort study was commenced for the detection of FGTB in Indian population for the first time. In the present study, we have demonstrated the use of a multi-gene PCR system based on the simultaneous amplification of the species-specific $19 \mathrm{kDa}$ antigen gene, MTB complex specific TRC4 
element and MPB64 antigen gene and genus specific $32 \mathrm{kDa}$ protein gene in a single step reaction, by which MTB can be indentified and distinguished from other nontuberculous mycobacteria among endo-ovarian tissue biopsies and PAFs. This study supporting the use of endometrial tissue biopsy, ovarian tissue biopsy, endometrial aspirations, pelvic aspirated fluids and fluid samples from the pouch of Douglas (POD), therefore endorses the study by Bhanu et al on the importance of multiple sampling in aiding the diagnosis of FGTB $[17,18]$. At present, almost all genes of multi gene PCR were in the use for routine examinations of FGTB. However, this method may be limited in the diagnosis, because TRC4 element is present in all south Indian specific MTB complexes and it may not be suitable for other population. Further, a huge number of clinical isolates of $M$. tuberculosis from south India had either a single copy (40\%) or no copy (4\%) of IS6110 [39,40]. But, the use of the multi-gene PCR system would not have the pitfalls caused by the absence of TRC4 element and IS6110 element from the particular region and mycobacteria, since DNA fragments corresponding to the amplification of $19 \mathrm{kDa}$ antigen gene, MPB64 antigen gene and $32 \mathrm{kDa}$ protein gene would still be present. The advantage of discriminating $M$. tuberculosis from nontuberculous mycobacteria in a single tube-single step reaction would lie in the possibility of using $19 \mathrm{kDa}$ antigen gene and the TRC4 element, to identify the particular type of mycobacteria under the study. $32 \mathrm{kDa}$ protein gene showed higher sensitivity and specificity than any other gene due to the presence of infectious organisms representing Mycobacterium genus. Even 19kDa antigen gene and TRC4 element showed better sensitivity (86.63\%) and specificity (100\%) [43,53]. Thus, these genes could be emerging future diagnostic biomarkers in the detection of FGTB (Pearson $\chi 2=206.011$, 1df, Fisher's exact test ( $\mathrm{p}$ value $)=0.000$, McNemar's test value $<0.0001)[38,39]$. These results are similar to those at Mycobacterium genus and $M$. tuberculosis complex levels obtained in fine needle aspirates in 35 (87.5\%) of the 40 patients with clinical and cytological diagnosis of tuberculous lymphadenitis $[17,43]$ and others by using single step PCR [29,43]. MPB64 gene could be appropriate or useful in the detection of $M$. tuberculosis complex but our results revealed that the role of MPB64 gene is limited to the detection of $M$. Bovis among patients with FGTB. This may suggest mutations within the MPB64 gene, leading to the production of an incomplete protein as a result of deletion in the C-terminal region of the protein [57]. The results of this study inveterate that TRC4 element might be universally detected, especially among so called south Indian strain of M. tuberculosis [56]. Hence, the combination of $19 \mathrm{kDa}$ antigen gene with TRC4 element could be a better choice in the detection of FGTB using endo-ovarian tissue biopsy and pelvic aspirated fluids and the positive multi-gene PCR results can be given due importance (Table 6). Increasing the awareness and importance of incorporating multiple genes targeting different characteristics of infectious agents in a single tube-single step reaction using multi-gene PCR method is needed. Information of this investigation will be made available online, particularly in cases, where the data is not published. Culturing of decontaminated and concentrated (DC) tissue sediments on L-J egg media and subsequent staining with $\mathrm{Z}-\mathrm{N}$ stain have been showed significant increase in AFB positive cases than direct staining of DC tissue specimens. Thus, culturing of tissue specimen was recommended prior to report the samples as AFB negative.

\section{Conclusion}

Our results clearly demonstrated that multi-gene PCR showed a significant advantage over the conventional techniques, in that the minimal detection limits of bacilli without the use of radioisotopes, without the use of costly and complex equipments and more than that three target genes can be studied at a time (Pearson $\chi 2=214.612$, 1df, Fisher's exact test value $<0.0001$, McNemar's test value $<0.0001$ ) [52]. As, we find clear and accurate banding patterns by agarose gel electrophoresis, sequencing of the PCR product was not suggested. This multi-gene PCR method also reveals that mycobacterial DNA is consistently observed more in ETBs (49.5\%) and OTBs (33.17\%) and very low in PAFs (5.44\%). Suggesting that, the presence of localized and latent tuberculosis infection such as FGTB can be detected by taking the site specific sampling, irrespective of sample types. This method can be utilized not only for bacteriological presence but also in the clinical findings of host in response to infectious agents. Exclusion criteria such as severe psychiatric dysfunction, multiple sclerosis or other autoimmune disorders, women with diabetes, malnutrition and other medical disorders like hypertension have been reported early to have a stimulated influence on the host immune response and can also increase the risk of developing tuberculosis [58,59]. This could mask the immune reaction produced by $\mathrm{TB}$ infections, may cause infertility and role of subclinical symptoms may not be conclusive. The results mentioned here demonstrate that $M$. tuberculosis was present in sufficient density among samples and can be detected surety by multi-gene PCR. It seems improbable that reporting of FGTB would result in a spurious over-representation of women with infertility. Multi-gene PCR was found to be a powerful technique for diagnosis and differentiation of mycobacterial infection. Since $32 \mathrm{kDa}$ protein is encoded by Mycobacterium genus specific gene, we suggest amplification of the $19 \mathrm{kDa}$ antigen gene in combination with TRC4 element as a successful multi-gene PCR method for the diagnosis of FGTB among infertile patients using both cultured and uncultured endo-ovarian tissue biopsies and pelvic aspirated fluids.

\section{Acknowledgements}

The authors acknowledge the help of Dr Bhukya Bhima, Dept of Microbiology; Dr C Srinivasulu, Dept of Zoology; Dr Raju Padiya, Dept of Biochemistry; Mr Venu and Mr Prabhakar, C/o Prof T Naga Raju, Dept of Zoology, UCS, Osmania University, Hyderabad for giving some especial chemicals required for isolation of mycobacterial DNA.

\section{References}


[1] Scrimin F, Limone A, Wiesenfeld U, Guaschino S. Tubercular endometritis visualized as endometrial micropolyps during hysteroscopic procedure. Arch Gynecol Obstet 2010; 281(6): 1079-80.

[2] Tripathy SN, Tripathy SN. Gynaecological tuberculosis -an update. Indian J Tuberc 1998; 45: 193-7.

[3] Aka N, Vural EZ. Evaluation of patients with active pulmonary tuberculosis for genital involvement. J Obstet Gynaecol Res 1997; 23(4): 337-40.

[4] M J Jassawalla. Genital tuberculosis - a diagnostic dilemma. J Obstet Gynecol India 2006; 56 (3): 203-204.

[5] Mani R, Nayak S, Kagal A, Deshpande S, Dandge N, Bharadwaj R. Tuberculous endometritis in infertility: a bacteriological and histopathological study. Indian J Tuberc 2003; 50: 161.

[6] Marjorie PG, Holenarasipur RV. Extrapulmonary tuberculosis: an overview. Am Fam Physician 2005; 72: 1761-8.

[7] Tripathi SM. Infertility and pregnancy outcome in female genital tuberculosis; Int J Gynecol Obstet 2002; 76(2): 159-63.

[8] Namavar Jahromi B, Parsanezhad ME, Ghane-Shirazi R. Female genital tuberculosis and infertility. Int J Gynaecol Obstet 2001; 75: 269-272.

[9] Dam P, Shirazee HH, Goswami SK, Ghosh S, Ganesh A, Chaudhury K, Chakravarty B. Role of latent genital tuberculosis in repeated IVF failure in the Indian Clinical setting. Gynecol Obstet Invest 2006; 61(4): 223-227.

[10] Parikh FR, Naik N, Nadkarni SG, Soonawala SB, Kamat SA, Parikh RM. Genital tuberculosis - a major pelvic factor causing infertility in Indian women. Fertil Steril 1997; 67: 497-500.

[11] Chakrabarti AK, Sen S, Banerjee A, Roy K. Female genital tuberculosis- a retrospective study. Ind J Tub 1998; 45: 101-3.

[12] Nawaz K. Frequency of endometrial tuberculosis: a histopathological study of endometrial specimens. J Postgrad Med Inst 2005; 19(1): 97-100.

[13] Ismael Kassim, Ray CG (editors). Sherris Medical Microbiology ( $4^{\text {th }}$ ed.) McGraw Hill. 2004.

[14] Parrish NM, Dick JD, Bishai WR. Mechanisms of latency in Mycobacterium tuberculosis. Trends Microbiol 1998; 6: 107-12.

[15] Ben Youssef LB, Chelli H, Belhadj A. Current anatomo-clinical aspects of genital tuberculosis in women. Apropos of 49 cases. J Gynecol Obstet Biol Reprod (Paris) 1985; 14: 59-65.

[16] Varma TR. Genital tuberculosis and subsequent fertility. Int J Gynecol Obstet 1991; 35: 1-11.

[17] N Vijaya Bhanu, Urvashi B Singh, Milan Chakraborty, Naga Suresh, Jyoti Arora, Tanu Rana, D Takkar, Pradeep Seth. Improved diagnostic value of PCR in the diagnosis of female genital tuberculosis leading to infertility. J Med Microbiol 2005; 54: 927-931.

[18] Thangappah RBP, Paramasivan CN, Narayanan S. Evaluating PCR, culture and histopathology in the diagnosis of female genital tuberculosis. Indian J Med Res 2011; 134: 40-46.

[19] Raut VS, Mahashur AA, Sheth SS. The mantoux test in the diagnosis of genital tuberculosis in women. Int J Gynaecol Obstet 2001; 2: 165-9.

[20] Gogate S, Joshi S, Gogate A. Tubal factor in infertility endoscopic and microbiological evaluation. J Obstet Gynecol India 1994; 44: 282-5.

[21] Sweet RL, Mills J, Hadley KW, Blumenstock E, Schachter J, Robbie MO, et al. Use of laparoscopy to determine the microbiologic etiology of acute salpingitis. Am J Obstet Gynecol 1979; 134: 68-74.

[22] Kapoor N, Pawar S, Sirakova TD, Deb C, Warren WL, et al. Human granuloma in vitro model, for TB dormancy and resuscitation. PLoS One 2013; 8: e53657.

[23] Falk V, Ludviksson K, Agren G. Genital tuberculosis in women: analysis of 187 newly diagnosed cases from 47 Swedish hospitals during the ten-year period 1968 to 1977. Am J Obstet Gynecol 1980; 138: 933.

[24] Punnonen R, Kiilholma P, Meurman L. Female genital tuberculosis and consequent infertility. Int J Fertil 1983; 28(4): 235-8.

[25] Abebe M, Lakew M, Kidane D, Lakew Z, Kiros K, et al. Female genital tuberculosis in Ethiopia. Int J Gynaecol Obstet 2004; 84: 241-246.

[26] Simon HB, Weinstein AJ, Pasternak MS, et al. Genitourinary tuberculosis: clinical features in a general hospital population. Am J Med 1977; 63: 410
[27] Centers for Disease Control and Prevention. Nucleic acid amplification tests for tuberculosis. MMWR Morb Mortal Weekly Rep 1996; 45: 950-952.

[28] Cole ST, R Brosch, J Parkhill, T Garnier, C Churcher, D Harris, SV Gordon, K Eiglmeier, S Gas, CE Barry, F Tekaia, K Badcock, D Basham, D Brown, T Chillingworth, R Connor, R Davies, K Devlin, T Feltwell, S Gentles, N Hamlin, S Holroyd, K Jagels, BC Barrel. Deciphering the biology of Mycobacterium tuberculosis from the complete genome sequence. Nature 1998; 393: 537-544.

[29] Kusum Sharma, Vishali Gupta, Reema Bansal, Aman Sharma, Meera Sharma, Amod Gupta. Novel multi-targeted polymerase chain reaction for diagnosis of presumed tubercular uveitis. J Ophthal Inflamm and Infect 2013; 3: 25.

[30] Weigert K. Eine Kleine Verbesserung der haematoxylin-van Gieson-Methode. Z Wiss Mikr 1904; 2: 1-5.

[31] Van Gieson I. Laboratory notes of technical methods for the nervous system. New York Med J 1889; 50: 57-60.

[32] Sheehan D, Hrapchak B. Theory and practice of histotechnology, 2nd Ed, Battelle Press, Ohio. 1980; 235-237.

[33] Crookham J, Dapson R. Hazardous chemicals in the histopathology laboratory, $2^{\text {nd }} E D, 1991$, Anatech.

[34] Murray PR, EJ Baron, JH Jorgensen, MA Pfaller, RH Yolken (ed.) Manual of clinical microbiology, 8th ed. 2003. American Society for Microbiology, Washington, D.C.

[35] Kent PT, GP Kubica. Public health mycobacteriology: a guide for the level III laboratory. USDHHS, Centers for Disease Control, Atlanta. 1985.

[36] National Committee for Clinical Laboratory Standards. Approved guideline protection of laboratory workers from occupationally acquired infections, $2^{\text {nd }}$ ed. NCCLS, Wayne, Pa. 2001; M29-A2.

[37] Mustafa AS, Ahmed A, Abal AT, Chugh TD. Establishment and evaluation of a multiplex polymerase chain reaction for detection of mycobacteria and specific identification of Mycobacterium tuberculosis complex. Tuber Lung Dis 1995; 76(4): 336-43.

[38] Helen A Fletcher, Helen D Donoghue, G Michael Taylor, Adri GM van der Zanden, Mark Spigelman. Molecular analysis of Mycobacterium tuberculosis DNA from a family of $18^{\text {th }}$ century Hungarians. Microbiol 2003; 149: 143-151.

[39] Sujatha N, Vijayalakshmi P, Narayannan PR, Venkatesan P, Girish C, et al. Evaluation of PCR using TRC4 and IS6110 primers in detection of tuberculous meningitis. $\mathrm{J}$ Clin Microbiol 2001; 39: 2006-2008.

[40] Parandaman V, Narayanan S, Narayanan P. Utility of polymerase chain reaction using two probes for rapid diagnosis of tubercular pleuritis in comparison to conventional methods. Indian J Med Res 2000; 112: 47-51.

[41] Dil-Afroze, Abdul Waheed Mir, Altaf Kirmani, Shakeel-ulRehman, Rafiqa Eachkoti, et al. Improved diagnosis of central nervous system tuberculosis by MPB64-target PCR. Brazil J Microbiol 2008; 39: 209-213.

[42] Abdulmonam Saied Barouni, Halha Ostrensky Saridakis, Marilda Carlos Vidotto. Detection of mycobacterium in clinical samples by multi primer polymerase chain reaction. Brazil J Microbiol 2004; 35: 29-32.

[43] Kidane D, Olobo JO, Habte A, Negesse Y, Aseffa A. Identification of the causative organism of tuberculous lympadenitis in Ethiopia by PCR. J Clin Microbiol 2002; 11(40): 4230-4234.

[44] Del Portillo P, MC Thomas, E Martinez, C Maranon, B Valladares, et al. Multi-primer PCR system for differential identification of mycobacteria in clinical samples. J Clin Microbiol 1996; 34: 324328.

[45] Telenti A, F Marchesi, M Balz, F Bally, EC Bo"ttger, T Bodmer. Rapid identification of mycobacteria to the species level by polymerase chain reaction and restriction enzyme analysis. J Clin Microbiol 1993; 31: 175-178.

[46] Michael Ka"ser, Julia Hauser, Pamela Small, Gerd Pluschke. Large sequence polymorphisms unveil the phylogenetic relationship of environmental and pathogenic mycobacteria related to Mycobacterium ulcerans. Appl Environ Microbiol 2009; 75(17) 5667.

[47] William E Grizzle, Walter C Bell, Katherine C Sexton. Issues in collecting, processing and storing human tissues and associated information to support biomedical research. Cancer Biomark 2010; 9(1-6): 531-549.

[48] Robert M Vodegel, Marcelus CJM de Jong, Hillegonda J Meijer, Marijn B Weytingh, Hendri H Pas, et al. Enhanced diagnostic 
immunofluorescence using biopsies transported in saline. BMC Dermatol 2004; 4(10): 1-7. (Saline).

[49] T Krenacs, E Bagdi, E Stelkovics, L Bereczki, L Krenacs. How we process trephine biopsy specimens: epoxy resin embedded bone marrow biopsies. J Clin Pathol 2005; 58: 897-903. (TBS).

[50] Soumitesh Chakravorty, Jaya Sivaswami Tyagi. Novel multipurpose methodology for detection of mycobacteria in pulmonary and extrapulmonary specimens by smear microscopy, culture and PCR. J Clin Microbiol 2005; 43(6): 2697-2702.

[51] Ganoza CA, Ricaldi JN, Chauca J, Rojas G, Munayco C, et al. Novel hypertonic saline-sodium hydroxide (HS-SH) method for decontamination and concentration of sputum samples for Mycobacterium tuberculosis microscopy and culture. J Med Microbiol 2008; 57(Pt 9): 1094-8.

[52] Syun-Ichi T, Okuzumi K, Ishiko H, Ken-ichi N, Ohkubo A, Nagai R. Genus specific polymerase chain reaction for the mycobacterial dnaj gene and species-specific oligonucleotide probes. J Clin Microbiol 1993; 31: 446-450.

[53] Ramya Barani, Gopalsamy Sarangan, Tessa Antony, Soundararajan Periyasamy, Anupma Jyoti Kindo, et al. Improved detection of Mycobacterium tuberculosis using two independent PCR targets in a tertiary care centre in South India. J Infect Dev Ctries 2012; 6(1): 46-52.
[54] S. Lantheaume, S. Soler, B. Issartel, et al. "Peritoneal tuberculosis simulating advanced ovarian carcinoma: a case report," Gynecologie Obstetrique Fertilite 2003; 31(7-8): 624-626.

[55] Clarridge JE, RM Shawar, TM Shinik, BB Plikaytis. Large-scale use of polymerase chain reaction for detection of Mycobacterium tuberculosis in routine mycobacteriology laboratory. J Clin Microbiol 1993; 31: 2049-2056.

[56] Fauville-Dufaux M, B Vanfleteren, L De Witt, JP Vincke, JP Van Vooren, MD Yates, E Serruys, J Content. Rapid detection of tuberculous and non-tuberculous mycobacteria by polymerase chain reaction amplification of a 162 bp DNA fragment from antigen 85. Eur J Clin Microbiol Infect Dis 1992; 11: 797-803.

[57] Kazue Hirano, Akio Aono, Mitsuyoshi Takahashi, Chiyoji Abe. Mutations including IS6110 insertion in the gene encoding the MPB64 protein of capilia TB-negative Mycobacterium tuberculosis isolates. J Clin Microbiol 2004; 42(1): 390-392.

[58] Blanca I. Restrepo. Convergence of the tuberculosis and diabetes epidemics: renewal of old acquaintances. Clin Infect Dis 2007; 45(4): 436-438

[59] Lawn SD, Zumla AI. Tuberculosis. Lancet 2011; 378(9785): 5772. 